\title{
Intervensi Pemaparan Modul Resiko Utama Tambang Bawah Tanah terhadap Peningkatan Pengetahuan, Sikap, dan Praktik Kontrol Kritis Resiko Fatal pada Petugas Safety Lapangan
}

\author{
Ossa Yudo Novaryan ${ }^{1 *}$, Yuliani Setyaningsih ${ }^{2}$, Suroto $^{3}$ \\ ${ }^{1,2,3}$ Fakultas Kesehatan Masyarakat, Universitas Diponegoro, Indonesia \\ *oscar906326@gmail.com
}

\begin{abstract}
The issue of work safety in various industrial sectors is still important, especially about work accidents. Statistics reveal that unsafe action is a major cause of workplace accidents. One way to change unsafe action into behavior that prioritizes work safety is by giving intervention. Therefore, this study examines differences in knowledge, attitudes, and critical control practices of field safety officers before and after receiving the intervention to explain the main risk module for underground mining. This study used a quasi-experiment (quasi-experimental) with the type of pre-posttest control group design. This study involved 36 field safety officers consisting of 18 people as the control group and 18 people as the experimental group. Data analysis used Paired Sample T-Test and Mann Whitney difference test. The study results reveal that the intervention of exposure to the main risk module for underground mining can improve the knowledge, attitude, and practice of critical risk control for field safety officers in the Underground Mining Operations Division, PT Freeport Indonesia. The results of this study have important implications for some occupational health and safety (K3) practitioners in the mining industry.
\end{abstract}

Keywords: intervention, safety knowledge, safety attitudes, safety practices, safety behavior

\begin{abstract}
Abstrak
Permasalahan keselamatan kerja di berbagai sektor industri hingga saat ini masih menjadi isu penting terutama kaitannya dengan kasus kecelakaan kerja. Statistik mengungkapkan bahwa perilaku tidak aman manusia adalah penyebab utama kecelakaan kerja. Salah satu cara merubah perilaku tidak aman manusia menjadi perilaku yang mengutamakan keselamatan kerja yaitu dengan cara memberikan intervensi. Oleh karena itu, studi ini bertujuan untuk menguji perbedaan pengetahuan, sikap, dan praktik kontrol kritis risiko fatal petugas safety lapangan sebelum dan setelah mendapatkan intervensi pemaparan modul resiko utama tambang bawah tanah. Studi ini menggunakan quasi experiment (eksperimen semu) dengan jenis pre-posttest control group design. Studi ini melibatkan 36 petugas safety lapangan yang terdiri dari 18 orang sebagai kelompok kontrol dan 18 orang sebagai kelompok eksperimen. Analisis data menggunakan uji Paired Sample T-Test dan uji beda Mann Whitney. Hasil studi mengungkapkan bahwa intervensi pemaparan modul resiko utama tambang bawah tanah dapat meningkatkan pengetahuan, sikap, dan praktik kontrol kritis resiko fatal pada petugas safety lapangan di Divisi Operasi Tambang Bawah Tanah, PT Freeport Indonesia. Hasil studi ini memberikan implikasi penting pada sejumlah praktisi kesehatan dan keselamatan kerja (K3) pada industri pertambangan.
\end{abstract}

Kata kunci: intervensi, pengetahuan keselamatan, sikap keselamatan, praktik keselamatan, perilaku keselamatan 


\section{Pendahuluan}

Industri pertambangan di Indonesia merupakan industri padat karya yang menyerap banyak tenaga kerja. Bahkan jika dilihat lebih seksama, penyerapan tenaga kerja industri tambang Indonesia jauh lebih banyak dibandingkan negara lain [1], [2]. Sebagai bentuk dari industri yang komplek, Industri pertambangan memiliki berbagai macam bahaya dan risiko keselamatan kerja yang tinggi. Kecelakaan tambang dapat terjadi kapan saja, menimpa siapa saja yang berada dalam industri pertambangan tersebut, apabila identifikasi terhadap bahaya, penilaian risiko dan penetuan kontrol dari risiko tersebut tidak diterapkan dengan standar keselamatan dan kesehatan kerja yang tinggi [3].

Industri tambang memiliki karakteristik yang spesifik dibandingkan dengan jenis industri lainnya. Oleh karena itu industri pertambangan memiliki sistem manajemen keselamatan dan kesehatan kerja sendiri yang disebut, sistem manajemen keselamatan dan kesehatan pertambangan. Sistem ini mengatur segala kegiatan untuk melindungi dan menjamin pekerja tambang agar senantiasa sehat dan selamat dengan berbagai usaha pengelolaan kesehatan kerja, keselamatan kerja, lingkungan kerja secara sistematik, efektif dan efisien [4]. Implementasi dari sistem manajemen keselamatan dan kesehatan kerja yang sesuai standar dapat meningkatkan produktifitas sebuah industri pertambangan, mencegah terjadinya kecelakaan kerja dan penyakit akibat kerja dengan konsekuensi kecederaan ringan hingga kematian [5].

Berdasarkan data statistik dari Kementrian Energi dan Sumber Daya Mineral, selama tahun 2020 telah terjadi kecelakaan tambang yang berakibat kematian dengan jumlah 17 jiwa. Angka tersebut masih merupakan angka kematian yang tinggi dalam kecelakaan kerja sekalipun mengalami penurunan sebanyak 7 jiwa dibandingan dengan jumlah kecelakaan kerja yang berakibat fatal pada tahun 2019 [6]. Salah satu perusahaan tambang yang perlu dilakukan kajian terkait keselamatan kerja yaitu PT Freeport Indonesia.

PT Freeport Indonesia sebagai salah satu perusahaan pertambangan terbesar di Indonesia yang berbasis di Papua, telah mengalami 4 kasus kecelakaan kerja yang berakibat fatal dengan 5 korban jiwa selama tahun 2020. Salah satu kasus kecelakaan kerja yang terjadi pada tahun 2020 yang mengakibatkan meninggalnya pekerja kontraktor dikarenakan terjepit pada titik artikulasi alat berat. Kecelakaan kerja berakibat fatal lainnya yang terjadi pada akhir tahun 2020 melibatkan seorang pekerja kontraktor yang bekerja sebagai tim rock fall protection, jatuh dari ketinggian 50 meter, karena tidak menggunakan alat pelindung jatuh personal.

Dalam konteks ini, Divisi Operasi Tambang Bawah Tanah merupakan salah satu dari Divisi di PT Freeport Indonesia yang memiliki risiko kecelakaan kerja berakibat kematian tertinggi. Kondisi lingkungan kerja yang gelap, dingin, sempit, basah, licin, bising, lalu lintas peralatan berat yang padat, penggunaan bahan peledak, keberadaan gas berbahaya, instalasi listrik tegangan tinggi di dalam Tambang Bawah Tanah, curah hujan yang tinggi yang memicu terjadinya luncuran lumpur basah, jenis pekerjaan yang beragam dan permesinan dengan tenaga besar merupakan faktor-faktor yang menunjang terjadinya kecelakaan kerja yang memiliki konsekuensi ringan hingga fatal. Para praktisi K3 Divisi Operasi Tambang Bawah memiliki peran penting dalam melakukan inspeksi, audit, observasi pekerjaan, fasilitasi dan sosialisasi kepada pekerja Divisi Operasi Tambang Bawah Tanah mengenai implementasi kontrol kritis pada Program FRM (Fatal Risk Management), agar para pekerja dapat terhindar dari risiko kematian saat bekerja. Pemahaman yang baik tentang kontrol kritis, mutlak diperlukan oleh praktisi Keselamatan dan Kesehatan Kerja Divisi Operasi Tambang Bawah Tanah.

Berdasarkan kondisi tersebut, peningkatan pemahaman, sikap, dan praktik kontrol kritis pada petugas safety lapangan di PT Freeport Indonesia perlu dilakukan. Studi 
ini bertujuan untuk melakukan intervensi berupa pemaparan modul risiko utama Tambang Bawah Tanah. Pemaparan modul dimaksudkan untuk memberikan informasi tambahan seputar proses kontrol kritis pada pengelolaan manajemen risiko fatal. Di dalam modul risiko utama Tambang Bawah Tanah tersebut secara umum berisikan materi berupa visualisasi dan teks penjelasan mengenai deskripsi dari risiko fatal yang mungkin terjadi di area kerja Divisi Operasi Tambang Bawah Tanah, serta kontrol-kontrol kritis yang harus diterapkan sebelum dan selama melakukan pekerjaan di Tambang Bawah Tanah. Pemaparan modul risiko utama Tambang Bawah Tanah dipilih sebagai intervensi dengan tujuan untuk memberikan wawasan pengetahuan, perubahan sikap dan praktik kontrol kritis pada petugas safety lapangan. Selain itu, studi ini juga bertujuan untuk mengungkapkan apakah terdapat perbedaan pengetahuan, sikap dan praktik kontrol kritis sebelum dan sesudah pemaparan modul risiko utama Tambang Bawah Tanah kepada seluruh petugas safety lapangan di Divisi Operasi Tambang Bawah Tanah sebagai upaya untuk menekan serendah mungkin potensi risiko fatal yang dapat terjadi di area kerja Divisi Operasi Tambang Bawah Tanah.

\subsection{Perilaku Keselamatan Kerja}

Pada dasarnya, perilaku manusia mencakup keseluruhan kegiatan manusia, baik yang diamati secara langsung, maupun yang tidak dapat diamati oleh pihak luar [7]. Skinner menyebutkan bahwa perilaku merupakan respon seseorang terhadap stimulus dan rangsangan dari luar. Teori Skinner ini disebut teori "S-O-R" atau Stimulus - Organisme Respon, perilaku ini melalui proses stimulus terhadap organisme dan kemudian merespons [7]. Menurut Bloom membagi perilaku itu di dalam tiga domain, yaitu pengetahuan (knowlegde), sikap (attitude), dan tindakan (practice) [7]. Dengan demikian, perilaku keselamatan kerja mencakup pengetahuan, sikap, dan tindakan yang mendukung aktivitas pekerjaan untuk mendapatkan suatu keadaan yang aman dan selamat di tempat kerja.

Salah satu pendekatan terpenting dan efektif untuk pencegahan kecelakaan kerja adalah pendekatan perilaku [8] yang berfokus pada modifikasi perilaku pegawai [9]. Pendekatan ini dikenal sebagai pendekatan keselamatan berbasis perilaku [10]. Karena trend keselamatan kerja saat ini banyak membahas berbagai perawatan keselamatan yang berfokus pada perubahan perilaku tidak aman karyawan [11], [12].

Perilaku tidak aman dapat dibagi menjadi dua kategori: kesalahan dan pelanggaran. Kategori kesalahan terdiri dari meleset (slips), kehilangan (lapses), dan kesalahan (mistakes) [13]. Dalam kategori ini, perilaku yang tidak aman baik hasil dari kesalahan kelalaian (ketika tindakan yang diperlukan dihilangkan) atau dari kesalahan komisi (ketika perilaku yang tidak aman dilakukan). Namun demikian, orang yang melakukan kesalahan biasanya percaya bahwa tindakan mereka adalah pilihan yang lebih baik dan lebih efektif untuk menyelesaikan tugas. Kesalahan terkadang terjadi karena diyakini terdapat banyak lapisan pelindung [14]. Selain itu, menurut teori Loss Causation Model menyebutkan bahwa faktor-faktor penyebab kecelakaan yang menyebabkan kerugian (loss) terdiri dari faktor manajemen, penyebab dasar, penyebab langsung,dan incident [15].

\subsection{Intervensi Keselamatan (Safety Intervention)}

Semua praktik keselamatan yang diterapkan di tempat kerja berada di bawah satu atap sebagai sistem manajemen keselamatan [16], [17]. Praktik keselamatan yang baik di industri pertambangan dinilai sangat penting untuk ditegakkan guna mengembangkan perilaku pekerja yang positif. Bahkan, berbagai intervensi yang bertujuan untuk meningkatkan pengetahuan, sikap, dan praktik keselamatan kerja banyak disoroti oleh para akademisi dan praktisi [18]-[21]. Intervensi keselamatan sebagai langkah untuk mengubah atau menerapkan metode untuk meningkatkan keselamatan [22]. Beberapa contoh intervensi 
keselamatan diantaranya seperti program pelatihan, intervensi teknik, dan prosedur administratif termasuk di antara praktik keselamatan baru, termasuk program di tempat kerja atau tindakan untuk meningkatkan keselamatan dengan sengaja.

Selain itu, Shakioye dan Haight (2010) menyatakan bahwa manajemen keselamatan dalam organisasi terdiri dari dua tingkat intervensi utama yaitu human system dan technical system. Pada human system, intervensi keselamatan mengacu pada praktik apa pun untuk mengubah pengetahuan dan kognisi manusia, dengan mempertimbangkan praktik keselamatan yang secara langsung mempengaruhi pekerja. Sementara itu, pada technical system, intervensi keselamatan mengacu pada praktik apa pun yang memastikan lingkungan kerja yang aman, termasuk perencanaan keselamatan.

Dalam konteks ini, pengembangan dan penerapan intervensi keselamatan dalam bentuk pemaparan modul resiko utama tambang bawah tanah diharapkan dapat meningkatkan pengetahuan, sikap, dan praktik kontrol kritis resiko fatal pada petugas safety lapangan di Divisi Operasi Tambang Bawah Tanah PT Freeport Indonesia. Dengan demikian, hipotesis penelitian ini terdiri dari:

$\mathrm{H} 1$ = tidak terdapat perbedaan tingkat pengetahuan, sikap, dan praktik kontrol kritis resiko fatal kelompok kontrol pada pre-test dan post-test

$\mathrm{H} 2$ = terdapat perbedaan tingkat pengetahuan, sikap, dan praktik kontrol kritis resiko fatal kelompok eksperimen sebelum dan sesudah dilakukan intervensi pemaparan modul risiko utama di Tambang Bawah Tanah H3 = terdapat perbedaan kenaikan tingkat pengetahuan, sikap, dan praktik kontrol kritis resiko fatal kelompok kontrol dan kelompok eksperimen pemaparan modul risiko utama di Tambang Bawah Tanah

\section{Metoda Penelitian}

Jenis penelitian ini menggunakan quasi experiment (eksperimen semu) dengan menggunakan pre-posttest control group design (lihat Tabel 1). Penelitian digunakan untuk untuk memahami hubungan sebab akibat dengan melibatkan kelompok kontrol disamping kelompok eksperimental, yaitu penelitian yang dikerjakan untuk mengetahui pengaruh pemberian treatment atau perlakuan pada subjek penelitian. Intervensi atau perlakuan yang digunakan dalam penelitian ini yaitu pemaparan modul risiko utama tambang bawah tanah. Secara spesifik, prosedur penelitian meliputi:

a. Membagi petugas safety lapangan kedalam kelompok eksperimen dan kontrol secara acak.

b. Membagikan pre-test kepada kelompok eksperimen dan kontrol.

c. Melakukan observasi praktik kontrol kritis.

d. Memberikan pemaparan modul risiko utama di Tambang Bawah Tanah kepada kelompok ekperimen.

e. Menyerahkan modul kepada petugas safety lapangan untuk dipelajari sendiri.

f. Setelah 21 hari melakukan kegiatan post-test kepada kelompok eksperimen dan kelompok kontrol.

g. Melakukan observasi praktik kontrol kritis.

h. Tahap Penyelesaian

i. Melakukan pengumpulan seluruh data yang didapat.

j. Melakukan pengolahan, analisa, dan menyimpulkan data hasil penelitian dari kuesioner dan lembar observasi.

Pengukuran variabel penelitiannya dilakukan sebelum dan sesudah intervensi. Pengaruh intervensi penelitian diperoleh dari perbedaan kedua hasil pengukuran.

\begin{tabular}{lccc} 
& \multicolumn{3}{c}{ Tabel 1. Desain Penelitian } \\
\hline R1 & O1 & $\mathrm{X}$ & $\mathrm{O} 2$ \\
R2 & O3 & - & O4 \\
\hline
\end{tabular}

Keterangan:

$\mathrm{R} 1$ = Random (keadaan awal kelompok ekperimen); R2 $=$ Random (keadaan awal kelompok kontrol); $\mathrm{O} 1$ = pretest kelompok eksperimen; $\mathrm{O} 2$ = post-test kelompok eksperimen; $\mathrm{O} 3=$ pre-test kelompok control; $\mathrm{O} 4=$ posttest kelompok control; $\mathrm{X}=$ Intervensi pemaparan modul risiko utama di Tambang Bawah Tanah. 
Studi ini melibatkan petugas safety lapangan di Divisi Operasi Tambang Bawah Tanah, PT Freeport Indonesia yang berjumlah 36 orang. Adapun 36 orang tersebut terdiri dari 18 orang petugas safety lapangan sebagai kelompok eksperimen dan 18 dijadikan kelompok kontrol (lihat Tabel 2). Analisis data untuk menguji perbedaan dua kelompok yang sama (pre-test dan post-test) menggunakan Paired Sample T-Test. Sementara itu, pengujian beda yang melibatkan dua kelompok yang berbeda menggunakan uji beda Mann Whitney.

Tabel 2. Responden Penelitian

\begin{tabular}{clcc}
\hline No & Variabel & Frekuensi & $\begin{array}{c}\text { Prosentase } \\
(\mathbf{1 0 0 \%})\end{array}$ \\
\hline 1. & SMA & 8 & 22,2 \\
\hline 2. & D3 & 26 & 5,6 \\
\hline 3. & S1 & 72,2 \\
\hline & Masa Kerja & \\
\hline 1. & $<10$ & 17 & 47,2 \\
\hline 2. & $10-20$ & 16 & 44,4 \\
\hline 3. & $>20$ & 3 & 8,3 \\
\hline & Usia & & 30,6 \\
\hline 1. & $<35$ & 11 & 52,8 \\
\hline 2. & $35-45$ & 19 & 16,7 \\
\hline 3. & $>45$ & 6 &
\end{tabular}

\section{Hasil Penelitian}

\subsection{Uji Prasyarat}

Sebelum dilakukan pengujian terhadap hipotesis penelitian, maka diperlukan pengujian asumsi klasik atau uji prasyarat uji hipotesis yang meliputi uji normalitas dan uji homogenitas. Berdasarkan Tabel 3 diperoleh informasi bahwa keseluruhan kelompok data berpasangan (pre-test dan post-test) pada kelompok kontrol dan eksperimen menunjukkan perolehan nilai signifikansi $(\alpha)$ diatas 0.05 . Hasil tersebut menunjukkan bahwa data penelitian berdistribusi normal atau dapat dinyatakan sampel berasal dari populasi yang berditribusi normal. Sementara itu, hasil yang berbeda ditunjukkan pada selisih skor kelompok tidak berpasangan antara kelompok kontrol dan eksperimen. Perolehan nilai signifikansi pada kelompok tersebut dibawah 0,05 yang bermakna bahwa data tidak berdistribusi normal.

Tabel 3. Hasil Uji Normalitas

\begin{tabular}{|c|c|c|c|}
\hline \multirow[t]{2}{*}{ Variabel } & \multicolumn{3}{|c|}{ Shapiro-Wilk } \\
\hline & Statistic & df & Sig. \\
\hline $\begin{array}{l}\text { Pengetahuan } \\
\text { (kontrol, } \\
\text { eksperimen, pre- } \\
\text { test, post-test) }\end{array}$ & $\begin{array}{l}0.917 \text { - } \\
0.932\end{array}$ & 18 & $\begin{array}{l}0.113- \\
0.209\end{array}$ \\
\hline $\begin{array}{l}\text { Sikap (kontrol, } \\
\text { eksperimen, pre- } \\
\text { test, post-test) }\end{array}$ & $\begin{array}{l}0.939- \\
0.963\end{array}$ & 18 & $\begin{array}{l}0.276- \\
0.669\end{array}$ \\
\hline $\begin{array}{l}\text { Praktik (kontrol, } \\
\text { eksperimen, pre- } \\
\text { test, post-test) }\end{array}$ & $\begin{array}{l}0.927 \text { - } \\
0.972\end{array}$ & 18 & $\begin{array}{l}0.170- \\
0.827\end{array}$ \\
\hline $\begin{array}{l}\text { Selisih Skor } \\
\text { Pengetahuan } \\
\text { (kontrol dan } \\
\text { eksperimen) }\end{array}$ & $\begin{array}{l}0.253- \\
0.577\end{array}$ & 18 & .000 \\
\hline $\begin{array}{l}\text { Selisih Skor Sikap } \\
\text { (kontrol dan } \\
\text { eksperimen) }\end{array}$ & $\begin{array}{l}0.253- \\
0.577\end{array}$ & 18 & .000 \\
\hline $\begin{array}{l}\text { Selisih Skor Praktik } \\
\text { (kontrol dan } \\
\text { eksperimen) }\end{array}$ & $\begin{array}{l}0.477- \\
0.843\end{array}$ & 18 & $\begin{array}{l}0.000- \\
0.007\end{array}$ \\
\hline
\end{tabular}

Sementara itu, hasil uji homogenitas variabel penelitian yang meliputi variable pengetahuan, sikap, dan praktik pada kelompok berpasangan (pre-test dan post-test) menunjukkan perolehan nilai Levene Statistic berkisar antara $0.027-2.970$ dengan nilai signifikansi berkisar antara $0.094-0.871$ (lihat Tabel 4). Hasil perhitungan nilai signifikansi tersebut semuanya diatas 0.05 , maka dapat disimpulkan bahwa data dalam penelitian ini memiliki varians yang homogen. Sementara itu, pengujian homogenitas selisih skor pada kelompok tidak berpasangan antara kelompok kontrol dan eksperimen menunjukkan data memiliki varians yang sama pada selisih skor pengetahuan dan sikap. Namun, selisih skor praktik menunjukkan data tidak memiliki varians yang homogen. 
Tabel 4. Hasil Uji Homogenitas

\begin{tabular}{lrrrr}
\hline \multicolumn{1}{c}{ Variabel } & $\begin{array}{c}\text { Levene } \\
\text { Statistic }\end{array}$ & df1 & df2 & Sig. \\
\hline $\begin{array}{lrrrr}\text { Pengetahuan (pre- } \\
\text { test dan post-test) }\end{array}$ & $0.033-$ & 1 & 34 & 0.712 \\
& 0.139 & & & - \\
\hline Sikap (pre-test dan & $2.225-$ & 1 & 34 & 0.134 \\
post-test) & 2.353 & & & - \\
\hline Praktik (pre-test & $0.027-$ & 1 & 34 & 0.094 \\
dan post-test) & 2.970 & & & - \\
\hline Selisih skor & 1.163 & 1 & 34 & .288 \\
pengetahuan & & & & \\
\hline Selisih skor sikap & 1.163 & 1 & 34 & .288 \\
\hline Selisih skor praktik & 21.516 & 1 & 34 & .000 \\
\hline
\end{tabular}

\subsection{Uji Hipotesis}

Studi ini bertujuan untuk mengetahui perbedaan pengetahuan, sikap dan praktik kontrol kritis petugas safety lapangan sebelum dan sesudah intervensi pemaparan modul risiko utama di Tambang Bawah Tanah pada Divisi Operasi Tambang Bawah Tanah, PT Freeport Indonesia. Analisis yang digunakan adalah uji t dengan bantuan SPSS for windows versi 20 dapat dijelaskan secara rinci sebagai berikut:

a. Analisis perbedaan tingkat pengetahuan, sikap, dan praktik kontrol kritis kelompok kontrol pada pre-test dan post-test

Uji t pre-test dan post-test kelas kontrol bertujuan untuk mengetahui ada tidaknya peningkatan skor pengetahuan, sikap, dan praktik petugas safety lapangan tanpa pemberian intervensi pemaparan modul risiko utama di Tambang Bawah Tanah. Kesimpulan penelitian dinyatakan signifikan apabila perolehan nilai signifikansi lebih kecil dari 0,05 $(\alpha<0,05)$.

Berdasarkan hasil perhitungan Paired Sample T-Test pada Tabel 5. menunjukkan bahwa perolehan nilai signifikansi atau $\alpha$ sebesar 0,331-1,000. Angka tersebut lebih besar dari 0,05, artinya, tidak ada perbedaan tingkat pengetahuan kontrol kritis pre-test dan post-test pada kelompok kontrol. Temuan ini terlihat wajar karena kelompok kontrol tidak mendapatkan intervensi pemaparan modul kontrol kritis di Tambang Bawah Tanah sehingga aspek pengetahuan, sikap, dan praktik tidak mengalami perubahan yang signifikan.

Tabel 5. Ringkasan Hasil Uji t Berpasangan Pre-Test dengan Post-Test Kelas Kontrol

\begin{tabular}{lccc}
\hline \multicolumn{1}{c}{ Aspek } & t-hitung & df & Sig. (2-tailed) \\
\hline Pengetahuan & 1,000 & 17 & 0,331 \\
\hline Sikap & 0,566 & 17 & 0,579 \\
\hline Praktik & 0,000 & 17 & 1,000 \\
\hline
\end{tabular}

b. Analisis perbedaan tingkat pengetahuan, sikap, dan praktik kontrol kritis kelompok eksperimen sebelum dan sesudah dilakukan intervensi pemaparan modul risiko utama di Tambang Bawah Tanah

Selanjutnya, hasil analisis perbedaan tingkat pengetahuan, sikap, dan praktik kontrol kritis kelompok eksperimen sebelum dan sesudah dilakukan intervensi pemaparan modul risiko utama di Tambang Bawah Tanah ditunjukkan pada Tabel 6. Berdasarkan hasil perhitungan Paired Sample T-Test pada Tabel 6 menunjukkan bahwa perolehan nilai signifikansi atau $\alpha$ sebesar 0,000 baik pada aspek pengetahuan, sikap, dan praktik. Angka tersebut lebih kecil dari 0,05, artinya, terdapat perbedaan tingkat pengetahuan, sikap, dan praktik kontrol kritis pre-test dan post-test pada kelompok eksperimen. Rata-rata peningkatan skor kelompok eksperimen ini sebesar 0,94 untuk pengetahuan, 1,06 untuk sikap, dan 3,48 untuk praktik. Meskipun peningkatan skor tidak terlalu besar, namun pemberian intervensi pemaparan modul kontrol kritis di Tambang Bawah Tanah dinilai signifikan untuk meningkatkan pengetahuan, sikap, dan praktik kontrol kritis praktisi K3 Divisi Operasi Tambang Bawah Tanah, PT Freeport Indonesia. 
Tabel 6. Ringkasan Hasil Uji t Berpasangan Pre-Test dengan Post-Test Kelas Eksperimen

\begin{tabular}{lccc}
\hline \multicolumn{1}{c}{ Aspek } & t-hitung & df & Sig. (2-tailed) \\
\hline Pengetahuan & $-9,628$ & 17 & 0,000 \\
\hline Sikap & $-19,000$ & 17 & 0,000 \\
\hline Praktik & $-21,000$ & 17 & 0,000
\end{tabular}

c. Analisis perbedaan kenaikan tingkat pengetahuan, sikap, dan praktik kontrol kritis kelompok kontrol dan kelompok ekspierimen pemaparan modul risiko utama di Tambang Bawah Tanah

Pengujian ini dilakukan untuk memastikan apakah ada perbedaan pemberian intervensi pada kelompok yang berbeda yang terdiri dari kelompok kontrol dan kelompok eksperimen. Salah satu cara yang dapat dilakukan yaitu menguji selisih skor yang diperoleh dari pre-tes dan post-tes pada masingmasing kelompok. Selanjutnya, perbedaan selisih skor tersebut dianalisis menggunakan Uji Beda Mann Whitney. Pemilihan jenis uji tersebut dikarenakan data tidak berdistribusi normal.

Berdasarkan hasil perhitungan uji beda Mann Whitney pada Tabel 7 diketahui bahwa nilai signifikansi Mann-Whitney $U$ sebesasr .000 pada aspek pengetahhuan, sikap, dan praktik. Temuan ini menunjukkan bahwa nilai signifikansi lebih kecil dari 0,05, dan bermakna bahwa terdapat perbedaan yang signifikan peningkatan skor pengetahuan, sikap, dan praktik kontrol kritis para petugas safety lapangan di Divisi Operasi Tambang Bawah Tanah, PT Freeport Indonesia setelah pemberian intervensi pemaparan modul kontrol kritis utama di di Tambang Bawah Tanah.

Tabel 7 Ringkasan Hasil Uji Beda Mann Whitney Kenaikan Skor Kelas Kontrol dan Kelas Eksperimen

\begin{tabular}{lccc}
\hline Aspek & $\begin{array}{c}\text { Mann- } \\
\text { Whitney } \\
\mathbf{U}\end{array}$ & $\mathbf{Z}$ & $\begin{array}{c}\text { Asymp. Sig. } \\
\text { (2-tailed) }\end{array}$ \\
\hline Pengetahuan & 17.000 & -5.190 & 0,000 \\
\hline Sikap & 8.500 & -5.190 & 0,000
\end{tabular}

\begin{tabular}{lccc}
\hline Aspek & $\begin{array}{c}\text { Mann- } \\
\text { Whitney } \\
\mathbf{U}\end{array}$ & $\mathbf{Z}$ & $\begin{array}{c}\text { Asymp. Sig. } \\
\text { (2-tailed) }\end{array}$ \\
\hline Praktik & .000 & -5.430 & 0,000 \\
\hline
\end{tabular}

Hasil studi ini mempertegas studi sebelumnya bahwa pemberian intervensi dalam bentuk program keselamatan kerja dapat meningkatkan pengetahuan, sikap, dan praktik keselamatan kerja di tempat kerja. Misalnya, El-Gilany dkk. dalam studinya membuktikan bahwa keterlibatan teknisi laboratorium pada program intervensi tentang prosedur praktik terbaik laboratorium dapat meningkatkan skor pengetahuan, sikap, dan praktik keselamatan yang signifikan setelah pelaksanaan program pelatihan [23]. Upaya pemberian intervensi ini merupakan bentuk merubah perilaku keselamatan petugas. Karena hampir sebagian besar kasus kecelakaan kerja diakibatkan oleh rendahnya perilaku keselamatan para pekerja. Selain itu, perilaku keselamatan telah muncul sebagai faktor kunci dalam mencegah atau mengurangi kecelakaan kerja seperti cedera dan penyakit di tempat kerja.

Dalam studi ini, kondisi awal pengetahuan, sikap, dan praktik petugas safety lapangan terlihat rendah pada kelas eksperimen, namun setelah mereka mendapatkan intervensi dalam bentuk pemaparan modul resiko utama tambang bawah tanah menunjukkan adanya peningkatan skor pengetahuan, sikap, dan praktik control kritis resiko fatal. Sementara itu, pada kelas control yang tidak mendapatkan intervensi cenderung menunjukkan skor pengetahuan, sikap, dan praktik yang stabil dan bahkan beberapa responden mengalami penurunan skor. Hal ini terjadi dimungkinkan munculnya rasa kejenuhan sehingga mendorong penurunan kinerja terkait keselamatan kerja. Kelelahan akibat kerja dapat berdampak pada penurunan produktivitas, peningkatan kecelakaan kerja dan peningkatan angka absensi [24].

Jika dilihat secara keseluruhan, kenaikan skor pada kelas eksperimen mengalami peningkatan setelah mendapatkan intervensi, namun belum menunjukkan kenaikan skor yang 
besar. Meskipun demikian, kenaikan skor pada kesemua aspek menunjukkan hasil yang signifikan. Sebenarnya, intervensi pemaparan modul merupakan bagian intervensi edukasi kognitif. Intervensi tersebut sangat penting dilakukan untuk meningkatkan kesadaran dan pemahahan para petugas safety lapangan terkait keselamatan kerja. Menurut Schrader dan Lawless, meningkatkan kesadaran dan pemahaman (seperti pengetahuan) merupakan intervensi kunci untuk mempengaruhi dan meningkatkan sikap dan perubahan perilaku [25].

Awalnya, pemberian intervensi ini akan berdampak langsung pada pemahaman mereka. Selanjutnya, pengetahuan dan pemahaman tersebut akan mendorong individu untuk merubah sikap dan perilaku keselamatan kerjanya. Kesadaran yang terbentuk dari pengetahuan akan membantu dalam perubahan perilaku manusia. Semakin tinggi pengetahuan keselamatan kerja maka akan semakin besar dorongan seseorang untuk bersikap dan bertindak sesuai dengan prinsip-prinsip keselamatan dan kesehatan kerja khususnya dalam hal control kritis resiko fatal di tambang bawah tanah.

Upaya untuk melakukan internalisasi sikap keselamatan bagi para petugas safety lapangan perlu ditanamkan melalui penguatan pengetahuan mereka tentang resiko utama tambah bawah tanah dan pengontrolannya. Karena pada hakekatnya pencapaian tahap akhir sikap dalam bentuk penerimaan dimulai dari perhatian dan pengertian. Kedua aspek ini yaitu perhatian dan pengertian sangat erat kaitannya dengan seberapa besar informasi yang mereka pahami mengenai keselamatan kerja di tempat kerjanya. Studi sebelumnya menunjukkan bahwa pengetahuan mampu mempengaruhi sikap seseorang [25]. Dengan demikian, kegiatan pelatihan atau penyuluhan tentang pemaparan modul resiko utama tambah bawah tanah menjadi aspek penting dalam rangka membangun kesadaran mereka untuk membentuk sikap positif yang baik mengenai keselamatan kerja dan pada gilirannya akan membentuk perilaku keselamatan mereka.
Selain itu, manajamen perusahaan juga perlu memfasilitasi program-program keselamatan kerja bagi pekerja seperti penyediaan manajemen keselamatan kerja dan fasilitas keselamatan kerja.

\section{Kesimpulan}

Intervensi perilaku merupakan salah satu cara yang diyakini untuk merubah perilaku keselamatan yang mencakup pengetahuan, sikap, dan praktik keselamatan kerja. Dalam studi ini, pemberian intervensi dalam bentuk pemaparan modul resiko utama tambang bawah tanah mampu meningkatkan peningkatan pengetahuan, sikap, dan praktik control kritis resiko fatal petugas safety lapangan di Divisi Operasi Tambang Bawah Tanah, PT Freeport Indonesia. Hasil studi ini diharapakan memberikan implikasi penting pada sejumlah praktisi kesehatan dan keselamatan kerja (K3) pada industri pertambangan.

\section{Saran}

Hasil studi ini hanya sebatas mengkaji sejauh mana efek intervensi pada program keselamatan kerja terhadap perubahan pengetahuan, sikap, dan praktik keselamatan kerja. Namun, mekanisme mengontrol resiko dalam sebuah manajemen sistem keselamatan kerja di tambang bawah tanah belum dilakukan dengan komprehensif. Oleh karena itu, diperlukan penelitian terkait manajemen sistem keselamatan kerja di tambang bawah tanah berbasis resiko. Selain itu, kami menyadari penggunaan jumlah sampel penelitian ini terbilang sedikit. Oleh karena itu, untuk menyempurnakan studi ini maka penelitian berikutnya dapat menggunakan jumlah sampel yang lebih besar agar dapat digeneralisasi pada populasi yang lebih luas.

\section{Daftar Pustaka}

[1] E. Fernando, "Industri-PertambanganIndonesia-Tak-Kalah-Dengan-NegaraMaju," Dunia Tambang.co.id, Sep. 2020.

[2] M. Mardonova and Y. Choi, "Review of wearable device technology and its applications to the mining industry," 
Energies, vol. 11, no. 3, 2018, doi: 10.3390/en11030547.

[3] S. Abbasi, "Defining Safety Hazards and Risks in Mining Industry: A Case-Study in United States," Asian J. Appl. Sci. Technol. (Open Access Q. Int. J., vol. 2, no. 2, pp. 1071-1078, 2018.

[4] Kementerian Energi dan Sumber Daya Mineral Republik Indonesia, Peraturan Menteri Energi dan Sumber Daya Mineral Nomor 38 Tahun 2014 tentang Sistem Manajemen Keselamatan Pertambangan Mineral dan Batubara. Indonesia, 2014, p. 111.

[5] A. Nikulin and A. Y. Nikulina, "Assessment of occupational health and safety effectiveness at a mining company," Ecol. Environ. Conserv., vol. 23, no. 1, pp. 351355, 2017.

[6] M. O. Data, "Data Kecelakaan Tambang," 2020.

[7] S. Notoatmodjo, Promosi Kesehatan dan Perilaku Kesehatan. Jakarta: Rineka Cipta, 2012.

[8] D. Chen and H. Tian, "Behavior based safety for accidents prevention and positive study in China construction project," in Procedia Engineering, 2012, vol. 43, pp. 528-534, doi: 10.1016/j.proeng.2012.08.092.

[9] R. M. Choudhry, "Implementation of BBS and the Impact of Site-Level Commitment," J. Prof. Issues Eng. Educ. Pract., vol. 138, no. 4, pp. 296-304, Oct. 2012, doi: 10.1061/(ASCE)EI.1943-5541.0000111.

[10] S. Roberts and E. S. Geller, "Principles of Behavior-Based Safety," Handbook of Safety Principles. pp. 677-710, Dec. 15, 2017 , doi: https://doi.org/10.1002/9781119443070.ch2 9.

[11] B. H. W. Guo, Y. M. Goh, and K. Le Xin Wong, "A system dynamics view of a behavior-based safety program in the construction industry," Saf. Sci., vol. 104, pp. 202-215, 2018, doi: https://doi.org/10.1016/j.ssci.2018.01.014.

[12] A. Sulistyorini, M. Z. Rahfiludin, and S. Suroto, "Determinan perilaku keselamatan kerja: Peran faktor personal penjamah makanan di warung lesehan Malioboro," $J$. Sains Terap., vol. 5, no. 2, pp. 77-85, 2019, [Online]. Available: https://jurnal.poltekba.ac.id/index.php/jst/ar ticle/view/677/487.

[13] S. Y. Choi, J. Park, Y. Kim, S. Kim, and W. Jung, "A study for Unsafe Act classification under crew interaction during proceduredriven operation," Ann. Nucl. Energy, vol. 96, pp. 187-196, 2016, doi: https://doi.org/10.1016/j.anucene.2016.05.0 20.

[14] S. C. Theophilus, V. N. Esenowo, A. O. Arewa, A. O. Ifelebuegu, E. O. Nnadi, and F. U. Mbanaso, "Human factors analysis and classification system for the oil and gas industry (HFACS-OGI)," Reliab. Eng. Syst. Saf., vol. 167, pp. 168-176, 2017, doi: https://doi.org/10.1016/j.ress.2017.05.036.

[15] F. E. J. Bird and G. L. Germain, Practical Loss Control Leadership. Loganville, Georgia: International Loss Control Institute, 1985.

[16] L. S. Robson et al., "The effectiveness of occupational health and safety management system interventions: A systematic review," Saf. Sci., vol. 45, no. 3, pp. 329-353, 2007, doi:

https://doi.org/10.1016/j.ssci.2006.07.003.

[17] E. Ai Lin Teo and F. Yean Yng Ling, "Developing a model to measure the effectiveness of safety management systems of construction sites," Build. Environ., vol. 41, no. 11, pp. 1584-1592, 2006, doi: https://doi.org/10.1016/j.buildenv.2005.06. 005.

[18] M. Mazlina Zaira and B. H. W. Hadikusumo, "Structural equation model of integrated safety intervention practices affecting the safety behaviour of workers in the construction industry," Saf. Sci., vol. 98, pp. 124-135, 2017, doi: https://doi.org/10.1016/j.ssci.2017.06.007.

[19] B. Bronkhorst, L. Tummers, and B. Steijn, "Improving safety climate and behavior through a multifaceted intervention: Results from a field experiment," Saf. Sci., vol. 103, pp. 293-304, 2018, doi: https://doi.org/10.1016/j.ssci.2017.12.009.

[20] B. Mullan, L. Smith, K. Sainsbury, V. Allom, H. Paterson, and A.-L. Lopez, "Active behaviour change safety interventions in the construction industry: A systematic review," Saf. Sci., vol. 79, pp. 139-148, 2015, doi: https://doi.org/10.1016/j.ssci.2015.06.004.

[21] K. Yu, Q. Cao, C. Xie, N. Qu, and L. Zhou, 
"Analysis of intervention strategies for coal miners' unsafe behaviors based on analytic network process and system dynamics," Saf. Sci., vol. 118, pp. 145-157, 2019, doi: https://doi.org/10.1016/j.ssci.2019.05.002.

[22] S. A. Oyewole and J. Haight, "Making the Business Case: Assessment of Safety Intervention And Optimization of Resource Allocation," Oct. 2009.

[23] A.-H. El-Gilany, S. El-shaer, E. Khashaba, S. A. El-dakroory, and N. Omar, "Knowledge, attitude, and practice (KAP) of 'teaching laboratory' technicians towards laboratory safety and waste management: a pilot interventional study," J. Hosp. Infect., vol. 96, no. 2, pp. 192-194, 2017, doi: https://doi.org/10.1016/j.jhin.2017.02.007.

[24] safetysign, "Kelelahan Ekstrem Akibat
Kerja (Fatigue), Apa Efeknya Bagi Pekerja Dan Bagaimana Cara Mengatasinya?," 2018.

https://www.safetysign.co.id/news/375/Kel elahan-Ekstrem-Akibat-Kerja-Fatigue-ApaEfeknya-Bagi-Pekerja-dan-BagaimanaCara-Mengatasinya (accessed Jun. 08, 2021).

[25] P. G. Schrader and K. A. Lawless, "The knowledge, attitudes, \& behaviors approach: How to evaluate performance and learning in complex environments," Perform. Improv., vol. 43, pp. 8-15, 2004. 